\title{
Lopinavir and Curcumin Directly Alters BAX/BCL2 and VEGF165b mRNA Levels to Suppress Human Squamous Cervical Carcinoma Cell Growth
}

\author{
Lopinavir y Curcumina Alteran Directamente los Niveles de ARNm de BAX/BCL 2 y VEGF \\ 165 para Suprimir el Crecimiento de Células de Carcinoma Cervical Escamoso Humano
}

\author{
Anthony Adefolaju Gbenga ${ }^{1}$ \& Anthony Mwakikunga ${ }^{2}$
}

\begin{abstract}
ADEFOLAJU, G. A. \& MWAKIKUNGA, A. Lopinavir and curcumin directly alters BAX/BCL2 and VEGF165b mRNA levels to suppress human squamous cervical carcinoma cell growth. Int. J. Morphol., 37(2):584-591, 2019.

SUMMARY: Following the success of the highly active antiretroviral therapy, the potential of multidrug combination regimen for the management of cancer is intensely researched. The anticancer effects of curcumin on some human cell lines have been documented. Lopinavir is a FDA approved protease inhibitor with known apoptotic activities. Dysregulated apoptosis is important for the initiation of cancer while angiogenesis is required for cancer growth and development, this study therefore investigated the effects of the combination of lopinavir and curcumin on cell viability, apoptosis and the mRNA expression levels of key apoptotic and angiogenic genes; BAX, BCL2 and VEGF165b in two human cervical cell lines; human squamous cell carcinoma cells - uterine cervix (HCS-2) and transformed normal human cervical cells (NCE16IIA). The two human cervical cell lines were treated with physiologically relevant concentrations of the agents for $120 \mathrm{~h}$ following which BAX, BCL2 and VEGF165b mRNA expression were determined by Real Time qPCR. The Acridine Orange staining for the morphological evaluation of apoptotic cells was also performed. The combination of lopinavir and curcumin up-regulated pro-apoptotic BAX and antiangiogenic VEGF165b but down-regulated the mRNA levels of anti-apoptotic BCL2 mRNA in the human squamous cell carcinoma (HCS-2) cells only. The fold changes were statistically significant. Micrographs from Acridine Orange staining showed characteristic evidence of apoptosis in the human squamous cell carcinoma (HCS-2) cells only. The findings reported here suggest that the combination of curcumin and the FDA approved drug-lopinavir modulate the apoptotic and angiogenic pathway towards the inhibition of cervical cancer.
\end{abstract}

KEY WORDS:Lopinavir; Curcumin; VEGF165b; BAX; BCL2; Cervical cancer.

\section{INTRODUCTION}

Cervical cancer is still one of the leading causes of cancer-related deaths around the world in spite of the many progresses that have been made in its prevention (such as vaccinations against several strains of the oncogenic Human papilloma virus) (Koh et al., 2015). Cervical carcinoma is the fourth most common cancer among women globally. But more significantly, cervical cancer has a more uneven global distribution because more than $85 \%$ of all cervical cancers and cervical cancer-related deaths occur in developing countries (Siegel et al., 2015; Thabethe et al., 2015).

Following the success of antiretroviral therapy, the importance of combination therapy against conditions such as cancer, have been emphasized (Bock \& Lengauer, 2012; Conde et al., 2016). As a result of the development of resistance against the available chemotherapeutic agents, the assessment of anticancer effects of several plant derived agents have received extensive attention (Arunkumar $e t$ al., 2005; Holohan et al., 2013). Given the widespread usage of curcumin as a spice and in reflection of the absence of toxicity even with high dosages, the use of the polyphenol for chemoprevention has been recommended for more investigation (Killian et al., 2012). Curcumin, shows chemo preventive and growth inhibitory activity against several tumour cell lines due to its anti-oxidant and anti-inflammatory activities (Noorafshan \& AshkaniEsfahani, 2013).

\footnotetext{
${ }^{1}$ Department of Pre-Clinical Sciences, School of Health Care Sciences, University of Limpopo, Private Bag x1106, Sovenga 0727, South Africa.

${ }^{2}$ Department of Biomedical Sciences, Anatomy Division, College of Medicine, University of Malawi, Blantyre, Malawi.
} 
Apoptosis (programmed cell death) is mediated by intrinsic and extrinsic pathways (Chipuk et al., 2008; Youle \& Strasser, 2008). The mitochondrial apoptotic pathway is regulated by pro-apoptotic genes like BAX and anti-apoptotic genes such as BCL2 (Chipuk et al., 2010). As a result, the ratio of pro-apoptotic to antiapoptotic gene-expression regulates the sensitivity of cells to death signals (Bai \& Wang, 2014), hence, the upregulation of BCL2 gene expression and/or downregulation of BAX is one of the important hallmarks of cancers (Green \& Beere, 1999; Adefolaju et al., 2015). The effects of the combination of lopinavir and curcumin on this important pathway would provide better insight into their anticancer potentials and underlying mechanisms.

There are many reports alluding to the apoptotic effects of the protease inhibitor-lopinavir (Batman et al., 2011; Kariya et al., 2014). In a previous study (Adefolaju et al., 2014), lopinavir demonstrated some (albeit not statistically significant) cervical cancer growth inhibition at clinical concentrations after a $96 \mathrm{~h}$ exposure. The effects of curcumin or its combinations (with lopinavir or any other anticancer agent) on the expression anti-angiogenic VEGF165b have not been previously studied. Angiogenesis - an important requirement for cancer growth is the development of a network of blood vessels that invade tumours and provide nutrients (Bates et al., 2013; Adefolaju et al., 2017). The Vascular Endothelial Growth Factor-A (VEGF-A) family has been shown to regulate angiogenesis and lymphangiogenesis (Bates et al.; Adefolaju et al., 2017). VEGF- A can be generated as multiple isoforms by alternative splicing. one of such families of isoforms that have been described in humans are pro-angiogenic isoforms VEGF-165a, and antiangiogenic isoforms VEGF-165b (Woolard et al., 2004; Bates et al.).

One of the aims of the present study was to investigate whether the expression of the anti-angiogenic VEGF splice variant; VEGF165b could be altered in cancer cervical and normal cervical cells exposed to lopinavir and curcumin, individually and/or in combination. A down-regulation would imply that these agents have pro-tumour activities while an up-regulation of VEGF165b would support their anti-tumour activities and further unveil their mechanisms of action. This study utilised physiologically relevant concentrations of the agents and evaluated their effects in cancer and normal cervical cells following a $120 \mathrm{~h}$ exposure with respect to cell viability, Acridine Orange staining and the mRNA expression levels of the apoptotic related BAX and BCL2 and anti-angiogenic VEGF165b.

\section{MATERIAL AND METHOD}

Cells. Human cervical squamous carcinoma cells (HCS-2) were obtained from the cell bank of Japanese Collection of Research Bio-resources (JCRB) and cultured in Eagle's Minimal Essential Medium (EMEM) (Lonza, Verviers, Belgium) supplemented with $15 \%$ fetal calf serum (FCS) (Gibco, Germany) together with L-Glutamine (Gibco, Germany). Transformed normal human cervical cells (NCE16IIA) were also bought from JCRB and grown in Keratinocyte Basal Medium KBM-GOLD (Lonza, Walkersville, MD USA) and supplemented with bovine pituitary extract, transferrin, hydrocortisone, human recombinant epidermal growth factor, insulin and epinephrine (Lonza, Walkersville, MD USA).

Cells were cultured and sub-cultured according to supplier's instructions, available at;

http://cellbank.nibio.go.jp/ cellbank/en/ search_res_det.cgi?ID $=5979$ (HCS-2)

http://cellbank.nibio.go.jp/ cellbank/en/ search_res_det.cgi?ID=3303 (NCE16IIA) and as described previously (Adefolaju et al., 2014).

Cells were cultivated as an adherent monolayer in tissue-culture dishes (Nunclon, Denmark) and were incubated at $37{ }^{\circ} \mathrm{C}$ in a $5 \% \mathrm{CO}_{2}$ humidified environment. Growth media were changed every $24 \mathrm{hrs}$.

Drugs and Treatment. Lopinavir was purchased from Toronto Research Chemicals (Ontario, Canada) while curcumin was obtained from Sigma (St Louis, MO, USA). Both cell lines were exposed to $15 \mu \mathrm{M}$ lopinavir and $20 \mu \mathrm{M}$ curcumin individually and in combination for $120 \mathrm{~h}$. The drugs were administered at physiologic concentrations as previously described (Adefolaju et al., 2014; Zhou et al., 2015) (KALETRA $®$, Abbott laboratories, 2010). Cells in the untreated and vehicle control groups were administered with the growth medium and vehicle respectively (Table I).

Table I. Shows the treatment groups and drug concentrations administered for each cell line.

\begin{tabular}{ll}
\hline Group & Treatment \\
\hline 1 & Growth Medium \\
2 & $0.01 \%$ DMSO \\
3 & $15 \mu \mathrm{M} \mathrm{LPV}$ \\
4 & $20 \mu \mathrm{M} \mathrm{CUR}$ \\
5 & $15 \mu \mathrm{M} \mathrm{LPV}+20 \mu \mathrm{M}$ CUR \\
\hline
\end{tabular}

Antibodies, Kits and reagents. Acridine Orange (AO) and the Neutral red TOX-4 kit, were purchased from Sigma Chemical Co. (St. Louis, MO, USA). Agarose D-1 Low EEOGQT was obtained from Conda Laboratories (Madrid, Spain). The DNase I, O'GeneRuler Low Range DNA Ladder, RNase- 
ADEFOLAJU, G. A. \& MWAKIKUNGA, A. Lopinavir and curcumin directly alters BAX/BCL2 and VEGF165b mRNA levels to suppress human squamous cervical carcinoma cell growth Int. J. Morphol., 37(2):584-591, 2019.

free kit and GeneJET RNA Purification kit were obtained from Thermo Scientific (Pittsburgh PA. USA). cDNA Reverse Transcription Kit and Power SYBR ${ }^{\circledR}$ Green PCR Master mix were obtained from Life technologies (California, USA). Oligomnucleotides for quantitative real time PCR were purchased from IDT Inc. (Coralville, Iowa, USA).

Neutral red viability assay. This assay evaluated the viability of cancer cervical and normal cervical cells after exposure to $15 \mu \mathrm{M}$ lopinavir and $20 \mu \mathrm{M}$ curcumin individually and in combination for $120 \mathrm{~h}$. The manufacturer's protocol was followed and as previously described (Adefolaju et al., 2014). After $120 \mathrm{~h}$ of treatment, cells were rinsed in phosphate buffered saline and the neutral red medium was added to each well. Plates were incubated for $2 \mathrm{~h}$ at $37^{\circ} \mathrm{C}$ for the neutral red dye to be taken up by viable cells. The neutral red dye was subsequently extracted and solubilised with $1 \%$ acetic acid in $50 \%$ ethanol for $10 \mathrm{~min}$ and the absorbance of the extracted dye was measured in a spectrophotometer (Anthos, Austria) at a wavelength of $540 \mathrm{~nm}$. Background absorbance was read at $690 \mathrm{~nm}$ and subtracted from the $540 \mathrm{~nm}$ measurement. All the experiments were conducted in replicates and repeated three times on three different days.

Acridine Orange (AO) staining. Both cell lines were routinely grown on $22 \mathrm{~mm}$ square coverslips placed into 35 mm culture dishes (Costar, Cambridge MA, USA) and treated with $0.01 \%$ DMSO and $15 \mu \mathrm{M}$ lopinavir and $20 \mu \mathrm{M}$ curcumin individually and in combination for $120 \mathrm{~h}$. This procedure evaluated the induction of apoptosis in these cell lines. After $120 \mathrm{~h}$, cells were stained with the AO dye mix for $5 \mathrm{~min}$. The dye mix was $100 \mathrm{mg} / \mathrm{mL}$ Acridine Orange in PBS. Acridine Orange permeates all cells, making the nuclei appear green. Live cells have a normal green nucleus; early apoptotic cells have bright green nucleus with condensed or fragmented chromatin; late apoptotic cells display condensed

Table II. Oligonucleotide sequences used for real time PCR.

\begin{tabular}{llc}
\hline Gene & Sequences (5'-3' direction) & $\begin{array}{l}\text { Product } \\
\text { size (bp) }\end{array}$ \\
\hline \multirow{2}{*}{ BAX } & F: CCT TTT CTA CTT TGC CAG CAA AC & 148 \\
BCL2 & $\begin{array}{l}\text { R: GAG GCC GTC CCA ACC AC } \\
\text { F: ATG TGT GTG GAG AGC GTC AAC C }\end{array}$ & 122 \\
VEGF165B & R: GCA TCC CAG CCT CCG TTA TC & 97 \\
FBP & R: CGC AGA CGT GTA AAT GTT CCT G & \\
RPLP0 & F: TGA TGC CTT ATG GCA CTG GAC TGA & 86 \\
TFRC & R: CTG CTG CCT TTG TTG CTC TTC CAA & \\
& F: TGC AGC TGA TCA AGA CTG GAG ACA & 178 \\
& R: TCC AGG AAG CGA GAA TGC AGA GTT & \\
& F: GGC ACC ATC AAG CTG CTG AAT GAA & 133 \\
\hline
\end{tabular}

and fragmented chromatin and membrane blebbing (Cañete et al., 2001; Adefolaju et al., 2015). After AO staining, culture dishes were inverted and fixed with formaldehyde vapour for $1 \mathrm{~min}$ to prevent the photo-damaging effects of continuous excitation on living cells due to the photosensitizing effects of most fluorescent dyes. A total of 500 cells per group were counted from three independent experiments to determine the percentage of apoptotic cells.

RNA Extraction, cDNA Synthesis, and qPCR Analysis. RNA extraction was performed after treating both cell lines for $120 \mathrm{~h}$. RNA concentration, purity and integrity was determined as previously described (Adefolaju et al., 2014). Genomic DNA was removed from the extracted RNA using the DNase I, RNase-free kit following manufacturer's instructions. Complementary DNA was synthesized using a GeneAmp® PCR System 12000 Thermal Cycler for $10 \mathrm{~min}$ at $25^{\circ} \mathrm{C}, 120 \mathrm{~min}$ at $37^{\circ} \mathrm{C}$. cDNA aliquots were then utilized in $\mathrm{qPCR}$ reactions for BAX and BCL2 and VEGF165b with TBP, RPLP0 and TFRC used as the endogenous reference genes. PCR reactions were amplified as described previously (Adefolaju et al., 2015, 2017). PCR amplification was performed in a final volume of $20 \mathrm{ml}$ using the Power SYBR® Green PCR Master mix with the ABI 7500 realtime PCR machine. Primer sequences and PCR product sizes are shown in Table II. To confirm the absence of nonspecific amplification, PCR products were separated on $3 \%$ agarose gels, stained with ethidium bromide and images acquired with the BioRad Gel Doc® XR (Model 170-8170 Segrate, Milan. Italy). Applied Biosystems ABI 7500 software was used to plot the melt curves for each PCR product. As described previously (Livak \& Schmittgen, 2001; Hellemans et al., 2007), the relative mRNA expression levels of target genes in each sample and the expression stability of the reference genes were calculated using the $\mathrm{qBase}^{\mathrm{PLUS}}$ software version 2.3 (Biogazelle, Zulte, Belgium).

Statistical Analysis. Absorbance values obtained from the neutral red and the number of apoptotic cells from the Acridine Orange experiments were captured as mean + standard deviation. The normal distribution and the homogeneity of the variance were verified using an $\mathrm{F}$ test $(\mathrm{P}<0.05)$, after which a one-way analysis of variance (where a significance level of $\mathrm{P}<0.05$ was set) was used to compare the means. The qBase ${ }^{\text {PLus }}$ software was used for the analysis of variance (ANOVA), with significance level set at $\mathrm{p}<0.05$ to determine whether the mRNA expression levels of the genes of interest differed significantly across the groups. 


\section{RESULTS}

Effects of lopinavir and curcumin on the viability of HCS-2 and NCE16IIA cervical cell lines. Using the neutral red assay, we evaluated the viability of cancer cervical and normal cervical cells after exposure to $15 \mu \mathrm{M}$ lopinavir and $20 \mu \mathrm{M}$ curcumin individually and in combination for $120 \mathrm{~h}$. Figure 1 showed that the combination significantly inhibited the growth of HCS-2 cells without any significant inhibition recorded individually. However, the viability of the normal cervical cells, were not significantly inhibited by neither the individual compounds nor their combination after $120 \mathrm{~h}$ of exposure.

Apoptotic response of cancer cervical and normal cervical cell lines to lopinavir and curcumin. Following a $120 \mathrm{~h}$ exposure to lopinavir and curcumin individually and in combination, the response of cancer cervical (HCS-2) and normal cervical (NCE16IIA) cells to apoptosis was tested employing the Acridine Orange staining. The data obtained demonstrated that the combination significantly induced apoptosis in the HCS-2 cells (Fig. 2). Apoptotic induction was not statistically significant in the cancer cervical cells
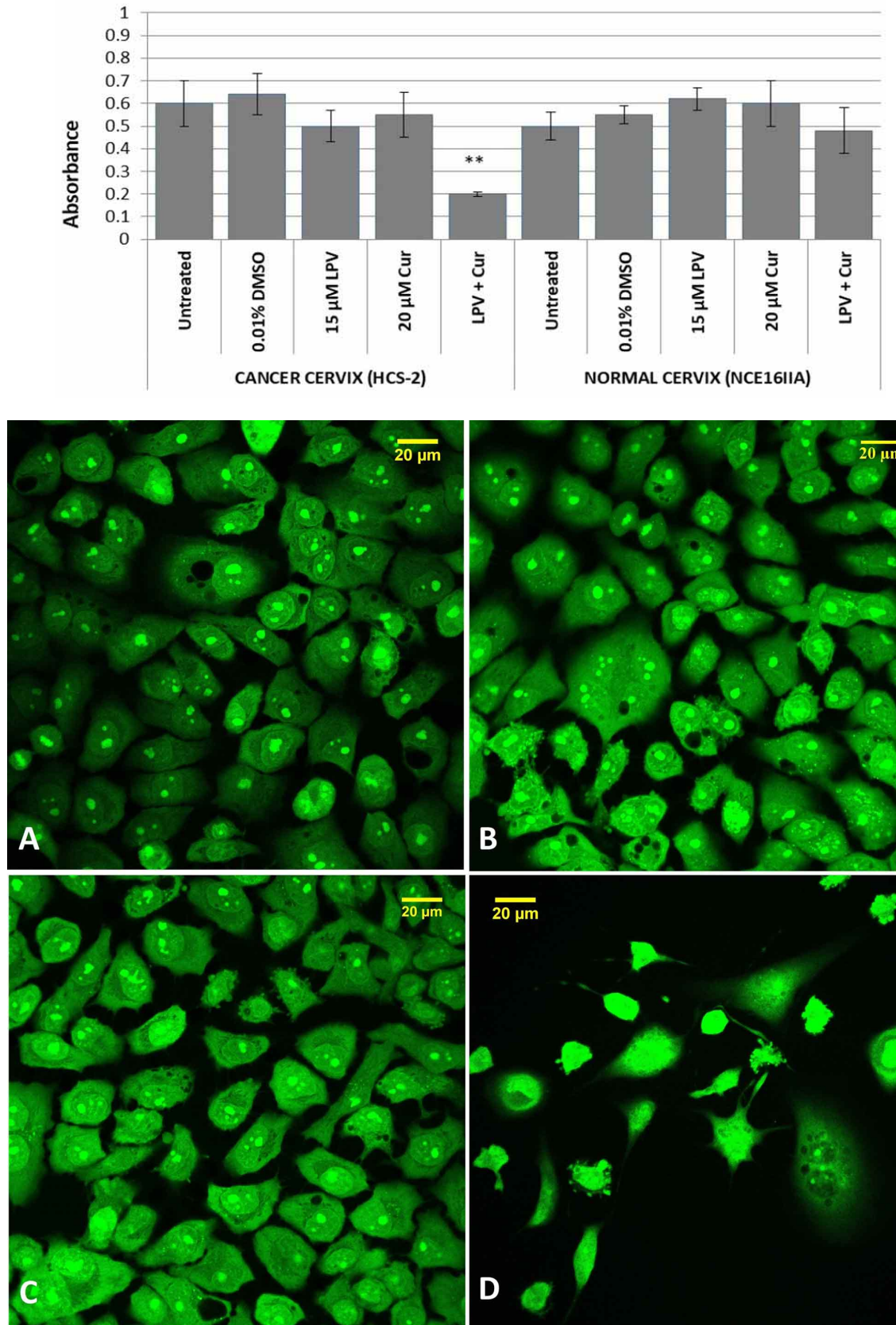
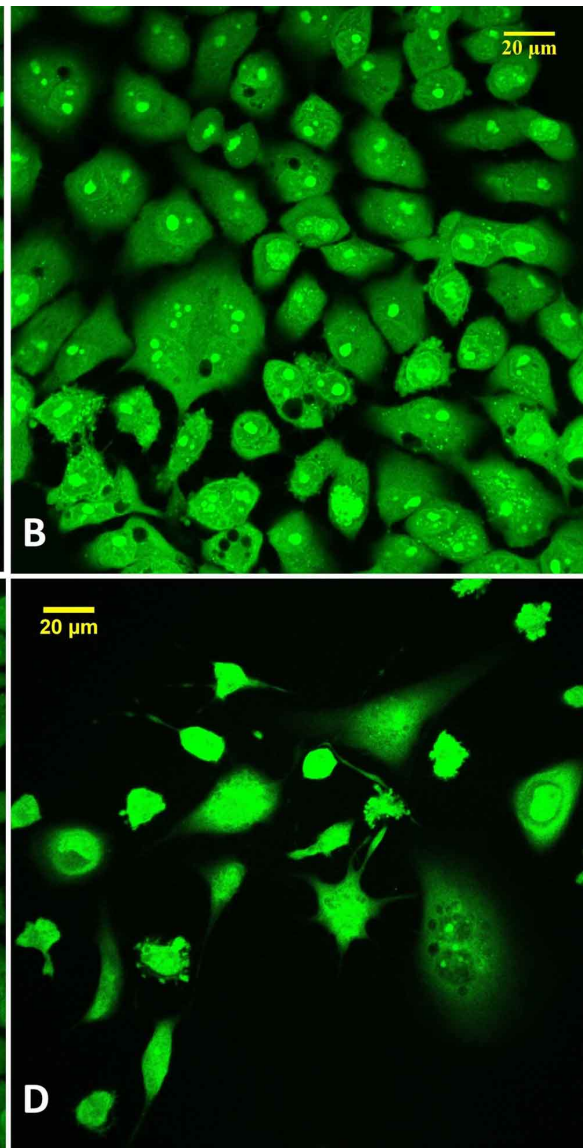

Fig. 1. Effects of LPV $(15 \mu \mathrm{M})$ and CUR $(20 \mu \mathrm{M})$ on the viability of cancer cervical HCS-2 and normal cervical NCE16IIA cells following $120 \mathrm{~h}$ of exposure. Cells were incubated with the compounds at the indicated concentrations. Graphs show mean + SEM from an average of three independent experiments. The combination of LPV and Cur exhibited significant $* *(\mathrm{P}<0.05)$ cytotoxic effects on the cancer cell line.
Fig. 2. Effects of LPV $(15 \mu \mathrm{M})$ and CUR $(20 \mu \mathrm{M})$ on apoptosis in cervical cancer HCS-2 cells. A: Untreated control HCS-2 cells. B. LPV treated HCS-2 cells. C. CUR treated HCS-2 cells. Apoptosis was assessed using acridine orange staining. Cells undergoing apoptosis show apoptotic bodies with the characteristic feature of membrane blebbing. A total of 500 cells per group were counted from 3 independent experiments to determine the percentage of apoptotic cells. LPV+CUR has significant apoptotic in HCS-2 cells (D). 
exposed to the individual compounds and apoptosis was neither significantly induced in the normal cervical cells exposed to the individual compounds nor the combination (Fig. 3).

This study determined the mRNA expression levels of the pro-apoptotic BAX, anti-apoptotic BCL2 as well as the anti-angiogenic VEGF splice variant VEGF165b after a $120 \mathrm{~h}$ treatment with lopinavir and curcumin (individually and in combination) in HCS-2 and NCE16IIA cervical cell lines.

After $120 \mathrm{~h}$, most significant was that the combination of LPV and CUR altered the mRNA expression patterns of the apoptotic genes BAX and BCL2 and also significantly down-regulated the mRNA expression of the antiangiogenic VEGF165b in the cancer cervical HCS-2 cells (Fig. 4). LPV alone seemed to increase the expression of BAX in the cancer cells but the changes did not attain statistical significance $(\mathrm{P}<.001)$. Also, the combination of LPV and CUR seemed to increase the expression of BAX in the normal cells but the differences were not statistically significant $(\mathrm{P}<.001)$. The normal cancer cells did not demonstrate significantly $(\mathrm{P}<.001)$ altered levels of all the examined genes after a 120 $\mathrm{h}$ treatment with lopinavir and curcumin individually and in combination. Results were analysed with the qBase ${ }^{\text {PLUS }}$ software and normalised to the expression levels of TBP, TFRC and RPLP0.
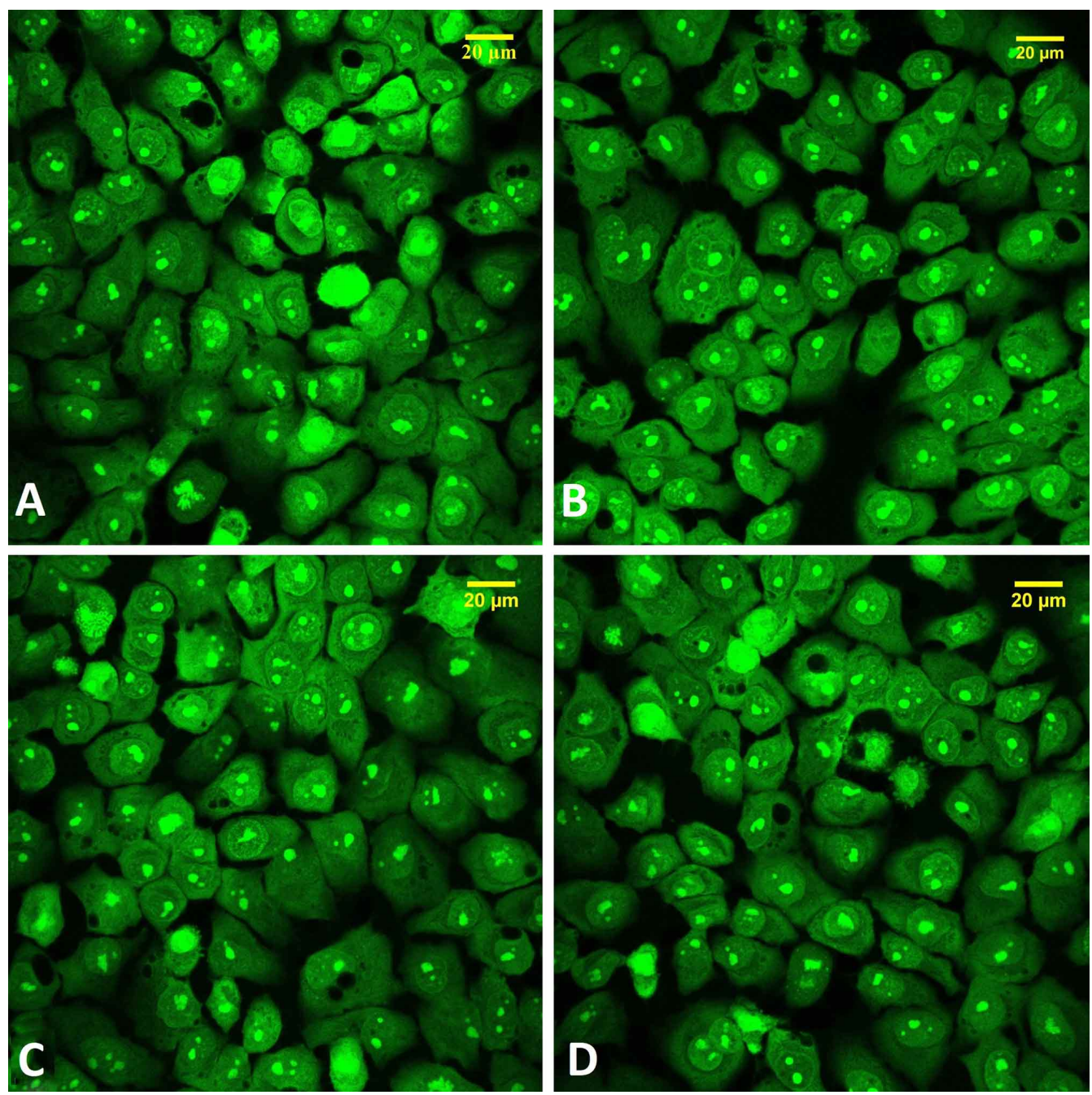

Fig. 3. Effects of LPV $(15 \mu \mathrm{M})$ and CUR $(20 \mu \mathrm{M})$ on apoptosis in normal cervical NCE16IIA cells. A: Untreated control NCE16IIA cells. B. LPV treated NCE16IIA cells. C. CUR treated NCE16IIA cells. Apoptosis was assessed using acridine orange staining. Cells undergoing apoptosis did not show apoptotic bodies with the characteristic feature of membrane blebbing. A total of 500 cells per group were counted from 3 independent experiments to determine the percentage of apoptotic cells. LPV+CUR has significant apoptotic in NCE16IIA cells (D). 


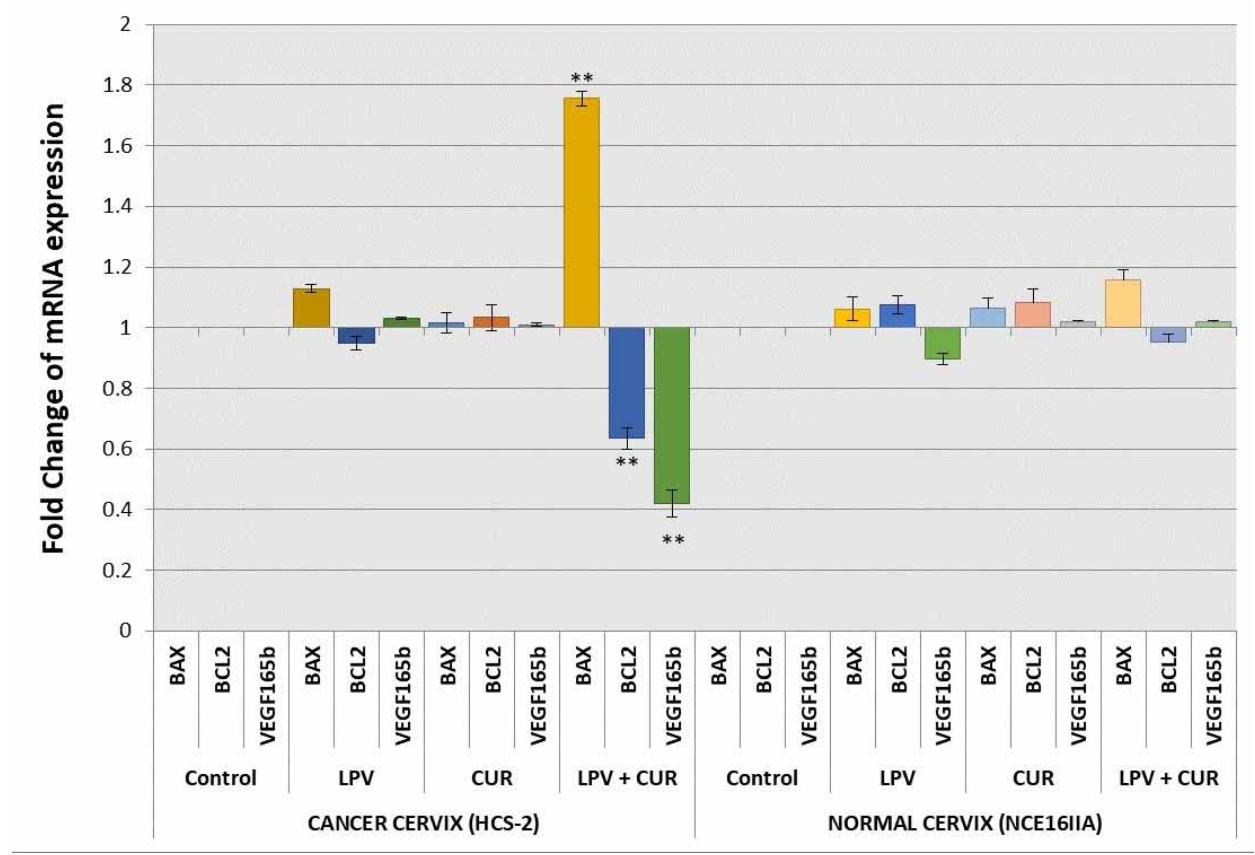

Fig. 4. Effects of LPV $(15 \mu \mathrm{M})$ and CUR $(20 \mu \mathrm{M})$ individually and in combination on the mRNA expression of BAX, BCL2 and VEGF165b in HCS-2 and NCE16IIA cervical cells following a 120 $\mathrm{h}$ treatment. The combination of LPV and CUR significantly $(* *)(\mathrm{P}<.001)$ altered the mRNA expressions of all the examined genes in the cancer cervical cell line alone. Data are fold changes and are representative of 3 independent experiments for RNA extraction.

\section{DISCUSSION}

Building upon the successes of the highly active antiretroviral therapy, the importance of combination therapy against conditions such as cancer, have been emphasized (Bock \& Lengauer; Liu et al., 2015; Conde et al.; Bayat Mokhtari et al., 2017). This project was thus designed to evaluate the anticancer effects of a combination of lopinavir and curcumin at physiologically relevant concentrations against an in-vitro model of cervical cancer vis-à-vis the normal cervical cells.

In a review of studies examining the therapeutic utility of curcumin, despite it's well documented cytotoxicity against cancer cell lines, Nelson et al. (2017) reported that "data on the effects of curcumin against normal (noncancerous) cell lines are sparse". They noted one report (Kuttan et al., 1985) which showed that curcumin showed cytotoxicity against normal human lymphocytes, albeit infrequently and concluded based on the literature available to them that curcumin does not show a preference for normal versus cancerous cells (Nelson et al.). Results from our study supports this idea because at physiologic concentrations of $20 \mu \mathrm{M}$, curcumin alone did not show any effects on the viability and mRNA expression levels of the apoptotic and antiangiogenic related genes that we studied in both cancer and normal cervical cells. But the combination of curcumin with lopinavir paints a different picture.

Curcumin has been shown to increase the sensitivity of cancer cells to chemo and radio-therapy (Chendil et al., 2004; Patel et al., 2010). For instance, a number of studies have documented the anticancer and chemo-preventive effects of curcumin against colorectal cancer (Roy et al., 2013; Toden et al., 2015; Hou et al., 2016). DU145 and LNCaP cells of prostate origin exposed to curcumin led to TNF-induced apoptotic death through the down-regulation of BCL2 and BCL-XL and the up-regulation of procaspases (Mukhopadhyay et al., 2001; Bommareddy et al., 2013). It is also reported that the apoptotic effects of curcumin seem to be varied depending on the prostate cancer cell line employed (Holy, 2004; Bommareddy et al.). In this study, we used novel prostate cancer cells (HCS-2) of Asian origin. Therapies utilising the drug class of HIV protease inhibitors are said to be an attractive new approach to cancer treatment and, due to their underlying mechanisms of action, are projected to successfully act against cancers that are refractory to existing treatment stratagems (Sato, 2015). The 
discovery of the apoptotic effects of HIV protease inhibitors including lopinavir led to the idea that this FDA approved drug could be redirected towards targeting cancer cells. For instance, Kariya et al. examined the effects of HIV protease inhibitors, lopinavir, ritonavir and darunavir on primary effusion lymphoma (PEL) cell lines. They found that lopinavir and ritonavir, but not darunavir produced caspase-dependent apoptosis and inhibited NF-kB activity by blocking IKK phosphorylation in the PEL cells. However, the dosages of lopinavir used in their study were much higher $25-40 \mu \mathrm{M}$ than physiologically relevant concentrations.

In a series of studies to support the use of lopinavir for the treatment of HPV-related pre-cancerous lesions of the cervix, Batman et al. showed that, at the optimum therapeutic dose range of $25 \mu \mathrm{M}$, lopinavir had much reduced toxicity in RNA-SEL siRNA transfected $\mathrm{SiHa}$ (cervical carcinoma) cells compared to better effects at higher non-optimal dose of $30 \mu \mathrm{M}$. Their lab also previously reported their observation that CaSki (cervical carcinoma) cells were insensi-tive to lopinavir (Kim et al., 2010).

After a literature search, no studies were found investigating the effects of the combination of lopinavir and curcumin on any model of cancer. This study was therefore designed to investigate the effects of the combination of lopinavir and curcumin on cell viability, apoptosis and the mRNA expression levels of key apoptotic genes such as BAX and BCL2 in two human cervical cell lines; human squamous cell carcinoma cells - uterine cervix (HCS-2) and transformed normal human cervical cells (NCE16IIA) of Asian origin. Our findings show that the combination of lopinavir and curcumin at clinically relevant concentrations (which reflect their steady-state peak plasma concentrations), altered the mRNA expression levels of apoptosis related BAX and BCL2 in the cancer cell line alone.

This study also investigated the effects of lopinavir and curcumin (individually and in combination) on a key factor (VEGF165b) in the angiogenic pathway. Protease inhibitors are considered to be strongly antiangiogenic compounds (Sgadari et al., 2002). Results from this study showed that after $120 \mathrm{~h}$, the combination of LPV and CUR significantly down-regulated the mRNA expression of the antiangiogenic VEGF165b in the cancer cervical HCS-2 cells without a noticeable change in the expression of the same genes in the normal cells. In addition, Apoptosis was induced in the cancer cervical cells exposed to the combination of lopinavir and curcumin but not in the individual compounds while apoptosis was not induced in the normal cervical cells exposed to both the individual compounds and the combination.
Our findings show that the combination of curcumin and the FDA approved drug-lopinavir at clinically relevant concentrations led to the inhibition of cervical cancer through their modulation of the apoptotic and angiogenic pathways.

ADEFOLAJU, G. A. \& MWAKIKUNGA, A. Lopinavir y curcumina alteran directamente los niveles de ARNm de BAX / BCL 2 y VEGF 165 para suprimir el crecimiento de células de carcinoma cervical escamoso humano. Int. J. Morphol., 37(2):584-591, 2019.

RESUMEN: Tras el éxito de la terapia antirretroviral altamente activa, se investiga intensamente el potencial del régimen de combinación de múltiples fármacos para el tratamiento del cáncer. Se han documentado los efectos anticancerígenos de la curcumina en algunas líneas celulares humanas. Lopinavir es un inhibidor de proteasa aprobado por la FDA con actividades apoptóticas conocidas. La apoptosis disrregulada es importante para el inicio del cáncer, mientras que la angiogénesis es necesaria para el crecimiento y desarrollo del cáncer. Por lo tanto, este estudio investigó los efectos de la combinación de lopinavir y curcumina sobre la viabilidad celular, la apoptosis y los niveles de expresión del ARNm de genes apoptóticos y angiogénicos clave: BAX, BCL2 y VEGF165b en dos líneas celulares cervicales humanas; células de carcinoma de células escamosas humanas: cérvix uterino (HCS-2) y células cervicales humanas transformadas (NCE16IIA). Las dos líneas celulares cervicales humanas se trataron con concentraciones fisiológicamente relevantes de los agentes durante 120 horas, después de lo cual la expresión de ARNm de BAX, BCL2 y VEGF165b se determinó mediante qPCR en tiempo real. También se realizó la tinción con naranja de acridina para la evaluación morfológica de células apoptóticas. La combinación de lopinavir y curcumina reguló incrementando BAX proapoptósicos y VEGF165b antiangiogénicos, pero reguló a la baja los niveles de ARNm del BCL2 antiapoptótico en células de carcinoma de células escamosas humanas (HCS-2) únicamente. Los cambios en el pliegue fueron estadísticamente significativos. Las micrografías de la tinción con naranja de acridina mostraron evidencia característica de apoptosis solo en las células del carcinoma de células escamosas humanas (HCS-2). Los hallazgos reportados aquí sugieren que la combinación de curcumina y el fármaco aprobado por la FDA lopinavir modulan la vía apoptótica y angiogénica hacia la inhibición del cáncer cervical.

PALABRAS CLAVE: Lopinavir; Curcumina; VEGF165b; BAX; BCL2; Cáncer cervical.

\section{REFERENCES}

Adefolaju, G. A.; Scholtz, K. E. \& Hosie, M. J. Antiangiogenic VEGF165b expression in human breast MCF-7 and MCF-10A cells exposed to reverse transcriptase and protease inhibitors. Int. J. Morphol., 35(1):14856, 2017.

Adefolaju, G. A.; Theron, K. E. \& Hosie, M. J. Effects of HIV protease, nucleoside/non-nucleoside reverse transcriptase inhibitors on Bax, Bcl2 and apoptosis in two cervical cell lines. Biomed. Pharmacother. 68(2):241-51, 2014.

Adefolaju, G. A.; Theron, K. E. \& Hosie, M. J. In-vitro effects of protease inhibitors on BAX, BCL- 2 and apoptosis in two human breast cell lines. South Afr. J. Sci., 111(11-12):1-9, 2015 
Arunkumar, A.; Vijayababu, M. R.; Kanagaraj, P.; Balasubramanian, K.; Aruldhas, M. M. \& Arunakaran, J. Growth suppressing effect of garlic compound diallyl disulfide on prostate cancer cell line (PC-3) in vitro. Biol. Pharm. Bull., 28(4):740-3, 2005.

Bai, L. \& Wang, S. Targeting apoptosis pathways for new cancer therapeutics. Annu. Rev. Med., 65:139-55, 2014.

Bates, D. O.; Mavrou, A.; Qiu, Y.; Carter, J. G.; Hamdollah-Zadeh, M.; Barratt, S.; Gammons, M. V.; Millar, A. B.; Salmon, A. H.; Oltean, S. \& Harper, S. J. Detection of VEGF-A(xxx)b isoforms in human tissues. PloS One, 8(7):e68399, 2013.

Batman, G.; Oliver, A. W.; Zehbe, I.; Richard, C.; Hampson, L. \& Hampson, I. N. Lopinavir up-regulates expression of the antiviral protein ribonuclease L in human papillomavirus-positive cervical carcinoma cells. Antivir. Ther., 16(4):515-25, 2011.

Bayat Mokhtari, R.; Homayouni, T. S.; Baluch, N.; Morgatskaya, E.; Kumar, S.; Das, B. \& Yeger, H. Combination therapy in combating cancer. Oncotarget, 8(23):38022-43, 2017.

Bock, C. \& Lengauer, T. Managing drug resistance in cancer: lessons from HIV therapy. Nat. Rev. Cancer, 12(7):494-501, 2012.

Bommareddy, A.; Eggleston, W.; Prelewicz, S.; Antal, A.; Witczak, Z.; McCune, D. F. \& Vanwert, A. L. Chemoprevention of prostate cancer by major dietary phytochemicals. Anticancer Res., 33(10):4163-74, 2013.

Cañete, M.; Juarranz, A.; López-Nieva, P.; Alonso-Torcal, C.; Villanueva, A. \& Stockert, J. C. Fixation and permanent mounting of fluorescent probes after vital labelling of cultured cells. Acta Histochem., 103(2):117-26, 2001.

Chendil, D.; Ranga, R. S.; Meigooni, D.; Sathishkumar, S. \& Ahmed, M. M. Curcumin confers radiosensitizing effect in prostate cancer cell line PC-3. Oncogene, 23(8):1599-607, 2004.

Chipuk, J. E.; Fisher, J. C.; Dillon, C. P.; Kriwacki, R. W.; Kuwana, T. \& Green, D. R. Mechanism of apoptosis induction by inhibition of the anti-apoptotic BCL-2 proteins. Proc. Natl. Acad. Sci. U. S. A., 105(51):20327-32, 2008.

Chipuk, J. E.; Moldoveanu, T.; Llambi, F.; Parsons, M. J. \& Green, D. R. The BCL-2 family reunion. Mol. Cell, 37(3):299-310, 2010.

Conde, J.; Oliva, N.; Zhang, Y. \& Artzi, N. Local triple-combination therapy results in tumour regression and prevents recurrence in a colon cancer model. Nat. Mater., 15(10):1128-38, 2016

Green, D. R. \& Beere, H. M. Killers or Clean-Up Crew. How Central are the Central Mechanisms of Apoptosis? In: Hickman, J. A. \& Dive, C. (Eds.). Apoptosis and Cancer Chemotherapy. Totowa, Humana Press, 1999. pp.157-74.

Hellemans, J.; Mortier, G.; De Paepe, A.; Speleman, F. \& Vandesompele, J. $\mathrm{qBase}$ relative quantification framework and software for management and automated analysis of real-time quantitative PCR data. Genome Biol., 8(2):R19, 2007.

Holohan, C.; Van Schaeybroeck, S.; Longley, D. B. \& Johnston, P. G. Cancer drug resistance: an evolving paradigm. Nat. Rev. Cancer, 13(10):714-26, 2013.

Holy, J. Curcumin inhibits cell motility and alters microfilament organization and function in prostate cancer cells. Cell Motil. Cytoskeleton, 58(4):253$68,2004$.

Hou, T. Y.; Davidson, L. A.; Kim, E.; Fan, Y. Y.; Fuentes, N. R.; Triff, K. \& Chapkin, R. S. Nutrient-gene interaction in colon cancer, from the membrane to cellular physiology. Annu. Rev. Nutr., 36:543-70, 2016.

Kariya, R.; Taura, M.; Suzu, S.; Kai, H.; Katano, H. \& Okada, S. HIV protease inhibitor Lopinavir induces apoptosis of primary effusion lymphoma cells via suppression of NF-kB pathway. Cancer Lett., 342(1):52-9, 2014.

Killian, P. H.; Kronski, E.; Michalik, K. M.; Barbieri, O.; Astigiano, S.; Sommerhoff, C. P.; Pfeffer, U.; Nerlich, A. G. \& Bachmeier, B. E. Curcumin inhibits prostate cancer metastasis in vivo by targeting the inflammatory cytokines CXCL1 and -2. Carcinogenesis, 33(12):2507-19, 2012.

Kim, D. H.; Jarvis, R. M.; Xu, Y.; Oliver, A. W.; Allwood, J. W.; Hampson, L.; Hampson, I. N. \& Goodacre, R. Combining metabolic fingerprinting and footprinting to understand the phenotypic response of HPV16 E6 expressing cervical carcinoma cells exposed to the HIV anti-viral drug lopinavir. Analyst, 135(6):1235-44, 2010.

Koh, W. J.; Greer, B. E.; Abu-Rustum, N. R.; Apte, S. M.; Campos, S. M.; Cho, K. R.; Chu, C.; Cohn, D.; Crispens, M. A.; Dorigo, O., et al. Cervical Cancer, Version 2.2015. J. Natl. Compr. Canc. Netw., 13(4):395-404, 2015.

Kuttan, R.; Bhanumathy, P.; Nirmala, K. \& George, M. C. Potential anticancer activity of turmeric (Curcuma longa). Cancer Lett., 29(2):197-202, 1985.
Liu, J.; Wang, C.; Wang, X.; Wang, X.; Cheng, L.; Li, Y. \& Liu, Z. Mesoporous silica coated single-walled carbon nanotubes as a multifunctional lightresponsive platform for cancer combination therapy. Adv. Funct. Mater. 25(3):384-92, 2015

Livak, K. J. \& Schmittgen, T. D. Analysis of relative gene expression data using real-time quantitative PCR and the 2(-Delta Delta C(T)) Method. Methods, 25(4):402-8, 2001.

Mukhopadhyay, A.; Bueso-Ramos, C.; Chatterjee, D.; Pantazis, P. \& Aggarwal, B. B. Curcumin downregulates cell survival mechanisms in human prostate cancer cell lines. Oncogene, 20(52):7597-609, 2001.

Nelson, K. M.; Dahlin, J. L.; Bisson, J.; Graham, J.; Pauli, G. F. \& Walters, M. A. The essential medicinal chemistry of curcumin. J. Med. Chem., 60(5):1620-37, 2017.

Noorafshan, A. \& Ashkani-Esfahani, S. A review of therapeutic effects of curcumin. Curr. Pharm. Des., 19(11):2032-46, 2013.

Patel, V. B.; Misra, S.; Patel, B. B. \& Majumdar, A. P. Colorectal cancer: chemopreventive role of curcumin and resveratrol. Nutr. Cancer, 62(7):95867, 2010.

Roy, S.; Yu, Y.; Padhye, S. B.; Sarkar, F. H. \& Majumdar, A. P. Difluorinatedcurcumin (CDF) restores PTEN expression in colon cancer cells by downregulating miR-21. PLoS One, 8(7):e68543, 2013.

Sato, A. The human immunodeficiency virus protease inhibitor ritonavir is potentially active against urological malignancies. Onco Targets Ther, 8:761-8, 2015.

Sgadari, C.; Barillari, G.; Toschi, E.; Carlei, D.; Bacigalupo, I.; Baccarini, S.; Palladino, C.; Leone, P.; Bugarini, R.; Malavasi, L., et al. HIV protease inhibitors are potent anti-angiogenic molecules and promote regression of Kaposi sarcoma. Nat. Med., 8(3):225-32, 2002.

Siegel, R. L.; Miller, K. D. \& Jemal, A. Cancer statistics, 2015. CA Cancer J. Clin., 65(1):5-29, 2015.

Thabethe, K. R.; Adefolaju, G. A. \& Hosie, M. J. The effects of HAART on the expression of MUC1 and P65 in a cervical cancer cell line, HCS-2. Biomed. Pharmacother, 71:227-32, 2015.

Toden, S.; Okugawa, Y.; Buhrmann, C.; Nattamai, D.; Anguiano, E.; Baldwin, N.; Shakibaei, M.; Boland, C. R. \& Goel, A. Novel evidence for curcumin and boswellic acid induced chemoprevention through regulation of miR34a and miR-27a in colorectal cancer. Cancer Prev. Res. (Phila.), 8(5):43143, 2015.

Woolard, J.; Wang, W. Y.; Bevan, H. S.; Qiu, Y.; Morbidelli, L.; Pritchard-Jones, R. O.; Cui, T. G.; Sugiono, M.; Waine, E.; Perrin, R., et al. VEGF165b, an inhibitory vascular endothelial growth factor splice variant: mechanism of action, in vivo effect on angiogenesis and endogenous protein expression. Cancer Res., 64(21):7822-35, 2004.

Youle, R. J. \& Strasser, A. The BCL-2 protein family: opposing activities that mediate cell death. Nat. Rev. Mol. Cell Biol., 9(1):47-59, 2008.

Zhou, M.; Fan, C. \& Tian, N. Effects of curcumin on the gene expression profile of L-02 cells. Biomed. Rep., 3(4):519-26, 2015.

Corresponding author:

Dr G.AAdefolaju

Department of Pre-Clinical Sciences

School of Health Care Sciences

University of Limpopo

Private Bag x1106

Sovenga 0727

SOUTH AFRICA

Email: gbenga.adefolaju@ul.ac.za anton.ul2016@gmail.com

Received: 10-09-2018

Accepted: 07-01-2019 